Kerry A. Dunn ${ }^{1}$, McIntyre R. Louthan, Jr. ${ }^{1}$, John I. Mickalonis ${ }^{1}$, Stuart Maloy ${ }^{2}$, Michael R. James ${ }^{2}$

\title{
Examination Of 304L Stainless Steel To 6061-T6 Aluminum Inertia Welded Transition Joints After Irradiation In A Spallation Neutron Spectrum
}

Dunn, K. A., Louthan, M. R., Jr., Mickalonis, J. I., Maloy, S, James, M. R., "Examination Of Irradiated 304L Stainless Steel To 6061-T6 Aluminum Inertia Welded Transition Joints," Effects of Radiation on Materials, ASTM STP 1405, S. E. Rosinski, Eds., American Society for Testing and Materials, West Conshohocken, PA, 19428-2959

Abstract: The Savannah River Technology Center (SRTC) designed and fabricated tritium target/blanket assemblies which were irradiated for six months at the Los Alamos Neutron Science Center (LANSCE). Cooling water was supplied to the assemblies through 1 inch diameter 304L Stainless Steel (SS) tubing. To attach the 304L SS tubing to the modules a 304L SS to 6061-T6 Aluminum (Al) inertia welded transition joint was used. These SS/Al inertia weld transition joints simulate expected transition joints in the Accelerator Production of Tritium (APT) Target/Blanket where as many as a thousand SS/Al weld transition joints will be used. Materials compatibility between the 304L SS and the 6061-T6 Al in the spallation neutron environment is a major concern as well as the corrosion associated with the cooling water flowing through the piping. The irradiated inertia weld examination will be discussed.

Keywords: Corrosion, irradiation, inertia weld, weld, pitting, interface, galvanic corrosion, aluminum, stainless steel, spallation

\section{Introduction}

The Accelerator Production of Tritium (APT) program is coordinated by Los Alamos National Laboratory (LANL) for the Department of Energy (DOE)/ Defense Programs (DP). As part of this program, the Savannah River Technology Center (SRTC) designed and fabricated tritium target/blanket assemblies which were sent to LANL and irradiated for six months at the Los Alamos Spallation Radiation Effects Facility (LASREF) at the Los Alamos Neutron Science Center (LANSCE). Cooling water was supplied to the assemblies through 1 inch diameter 304L stainless steel (SS) tubing. To attach the 304L SS tubing to the assemblies, a 304L SS to 6061-T6 Aluminum (Al) inertia welded transition joint was used.

\footnotetext{
${ }^{1}$ Fellow, Sr. Advisory, and Principal Engineers, respectively, Westinghouse Savannah River Company, 773-41A, Aiken, SC 29808

${ }^{2}$ Materials Team Leader, Staff Member, respectively, Los Alamos National Laboratory, MS H809 APT-TPO, Los Alamos, NM 87545
} 


\section{DISCLAIMER}

This report was prepared as an account of work sponsored by an agency of the United States Government. Neither the United States Government nor any agency thereof, nor any of their employees, make any warranty, express or implied, or assumes any legal liability or responsibility for the accuracy, completeness, or usefulness of any information, apparatus, product, or process disclosed, or represents that its use would not infringe privately owned rights. Reference herein to any specific commercial product, process, or service by trade name, trademark, manufacturer, or otherwise does not necessarily constitute or imply its endorsement, recommendation, or favoring by the United States Government or any agency thereof. The views and opinions of authors expressed herein do not necessarily state or reflect those of the United States Government or any agency thereof. 


\section{DISCLAIMER}

Portions of this document may be illegible in electronic image products. Images are produced from the best available original document. 


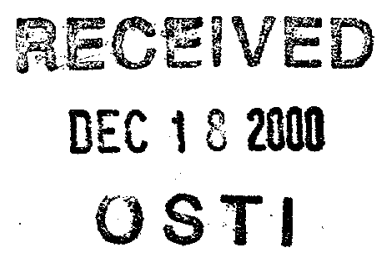

Four SS/Al weld transition joints were attached to each Mark I and Mark II assembly (two inlet and two outlet cooling lines). In addition, two SS/Al weld transition joints (one inlet and one outlet) were attached to each of three High Flux Assemblies. Several thousand of these inertia welds are currently in the design for the APT Target/Blanket (T/B). In the APT design, aluminum piping in the target/blanket region houses the ${ }^{3} \mathrm{He} /{ }^{3} \mathrm{H}$ gas. During production, this gas is transferred to the extraction and purification facility, where SS piping is used. The Al/SS inertia weld provides the path for gas flow between these two systems. Materials compatibility between the 304L SS and the 6061$\mathrm{T} 6 \mathrm{Al}$ in the radiation environment is a major concern as well as the corrosion associated with the cooling water that will interact with the piping in the APT facility.

Examination of the interior of the cooling water piping irradiated at LANSCE indicated that the cooling water chemistry provided a noticeable influence on the corrosion of both the inertia weld and the parent material. The effect of radiation on the inertia weld and surrounding area was evaluated against the cooling water effect. In addition, corrosion on the outside of the piping was investigated. This exterior corrosion is accelerated by the presence of nitric acid, which was formed by the radiolysis products of air and water from other components leaking during the irradiation.

Analyses of the irradiated 304L to 6061-T6 Al inertia welds included a variety of methods including visual examination, microstructural analysis, hardness measurements, optical microscopy, Scanning Electron Microscopy (SEM), Energy Dispersive Spectroscopy (EDS) and electrochemical corrosion testing. The data will be used to evaluate the concepts and methods for target/blanket manufacturing, materials and weld metal properties for spallation neutron environments, and joining methods for aluminum and aluminum to stainless steel.

\section{Experimental Design}

Several prototypical target/blanket assemblies were fabricated for irradiation testing in the LANSCE facility at LANL. These target/blanket assemblies consisted of lead encapsulated in aluminum. The lead surrounded Al tubes filled with either helium-3

$\left({ }^{3} \mathrm{He}\right)$ gas, or solid aluminum-lithium targets. The lead acted as a moderator and also provided an additional source of neutrons from $\mathrm{n}, \mathrm{xn}$ spallation reactions. Cooling water was supplied to the target/blanket assemblies in the LANSCE facility via 1-inch diameter 304L SS tubing. In order to transition from the SS cooling water tubing to the $\mathrm{Al}$ cooling water piping, a 304L stainless steel to 6061-T6 aluminum inertia welded transition joint was utilized [1]. The transition joint was machined from an inertia welded part made by Interface Welding [2], a commercial vendor. Certification data sheets, supplied by the vendor, showed that the solid state welds had a tensile strength equivalent to the 6061-T6 aluminum base metal in the T4 condition near the interface and a helium leak rate of approximately $10^{-9} \mathrm{cc}^{3} \mathrm{He} / \mathrm{sec}$. A piping schematic is shown in Figure 1 and the solid inertia welded piece prior to machining is shown in Figure 2.

The SS/Al inertia welded transition joints were welded to the inlet and outlet cooling lines of all test assemblies. A 304L sleeve was placed over the inertia welded section and Gas Tungsten Arc Welded (GTAW) to the stainless steel to prevent bending stresses during installation of the assembly. 
To ensure the appropriate analyses were being conducted, a task plan was developed for the overall target/blanket materials characterization which included the analyses of the irradiated transition joints [3]. This task plan outlined the deliberate and purposeful approach taken to accomplish the intended tasks.

A fixture and cutting apparatus (Figure 3) was designed, fabricated, and mocked up at SRS to support the sectioning of the irradiated inertia welded samples in the Chemical and Metallurgical Research (CMR) facility at LANL. The cutting apparatus was designed to provide ease of operation in the hot cells while working with hand operated or remote manipulators. Clean inertia welded transition joints were used in the mock-up operation at SRS to ensure the cutting apparatus would operate smoothly in the hot cells. Once the mock-up operation at SRS was complete the cutting apparatus was transferred to the LANL CMR hot cells.

Metallographic preparation equipment, which would be compatible with the hot cell environment, was purchased and mocked up at SRS prior to transfer to the LANL hot cells. Remote handling of the samples and the limited use of fluids in the hot cells needed to be considered for the operation. Several modifications to the equipment were made to make the equipment compatible with the hot cells. These modifications included the attachment of remote water lines to allow for the introduction of water from outside the hot cells and the displacement of the power operation to the exterior of the hot cells. Once the modifications and mock-up were completed the equipment was transferred to the LANL hot cells.

\section{Experimental Setup}

The prototypical lead/aluminum blanket assemblies were attached to the shielding inserts by welding the stainless steel water cooling lines to just above the transition joints as shown in Figure 4. The inserts were placed in a location downstream of the primary target inserts and outside ot the direct proton beam. Over the course of the six-month irradiation, the Mark I and Mark II assemblies saw a neutron fluence of approximately $8 \times 10^{19} \mathrm{n} / \mathrm{cm}^{2}$. The fluence from secondary protons was very small $\left(<3.0 \times 10^{18} \mathrm{p} / \mathrm{cm}^{2}\right)$. The High Flux assemblies, located closer to the tungsten spallation target, saw approximately $1 \times 10^{20} \mathrm{n} / \mathrm{cm}^{2}$ with a negligible proton fluence. The cooling water used for this particular irradiation at LASREF was the X02 water source, which was a recirculating water system that cooled many areas of the irradiation including a copper beam stop. Thermocouples placed on the outside of the cooling lines indicated that the temperatures in the location where the Mark I and Mark II, as well as the high flux assemblies, were maintained at approximately $30^{\circ} \mathrm{C}$.

Following irradiation, the assemblies were detached from the shielding inserts and transferred in a cask from LANSCE to the CMR facility at LANL where they were placed in the hot cells in Wing 9.

The fixture and cutting apparatus was used to separate the sleeve from the transition joints prior to sectioning the samples for further examination. Once the sleeve was removed the inertia welded transition joints were placed in the fixtures and sectioned in half and then one of the cut pieces was sectioned in half again, creating two $1 / 4$ sections and one $1 / 2$ section. After visual examination, a $1 / 4$ section of each transition joint was 
mounted for metallographic preparation. The remaining two pieces were available for additional testing, such as SEM/EDS or x-ray analysis.

Metallographic preparation of these specimens was not straightforward because of the dissimilar metals at the weld interface. Rounding of the aluminum edges was a great concern because $\mathrm{Al}$ is a softer material than stainless steel. However, metallographic preparation of the specimen using standard techniques for aluminum samples would not ensure that the stainless steel microstructure would be properly prepared for examination. An added intricacy was the fact that this metallographic preparation took place in the hot cells at LANL where remote handling was used and a minimum amount of liquids was allowed. Under these conditions, a metallographic technique was developed that provided the optimum operating parameters to ensure a properly prepared sample (Table 1 and Table 2). A baseline characterization of non-irradiated Al-SS inertia welded transition joints was completed to support the characterization of the irradiated transition joints [4].

A sample from each inertia welded transition joint was mounted and prepared metallographically. In addition, a non-irradiated inertia welded transition joint (control sample) was prepared metallographically in the hot cells to compare to the irradiated specimens.

Table 1 - Sample preparation sequence for metallographic analysis using automated grinder/polisher.

\begin{tabular}{|l|l|l|}
\hline Grinding/Polishing Sequence & $\begin{array}{l}\text { Preparation } \\
\text { Time (seconds) }\end{array}$ & Application Force $(\mathbf{N})$ \\
\hline $\begin{array}{l}500,600,800,1200,2400 \text { grit } \\
\text { SiC Papers }\end{array}$ & 90 (Each) & $100,150,100$ (Each) \\
\hline $1 \mu \mathrm{m}$ Diamond Nap Cloth & 240 & $200,150,100$ \\
\hline $6 \mu \mathrm{m}$ Diamond Nap Cloth & 240 & $200,150,100$ \\
\hline
\end{tabular}

Note: Application forces vary among the three listed for each preparation step.

Table 2 - Exposure times and compositions of etchants used in metallographic analysis.

\begin{tabular}{|c|c|}
\hline $\begin{array}{c}\text { Poulton's Etching Solution } \\
\text { (Al etchant) }\end{array}$ & $\begin{array}{c}\text { Oxalic Acid Solution } \\
\text { (SS etchant) }\end{array}$ \\
\hline $50 \mathrm{~mL}$ Poulton's Reagent & 10 g oxalic acid \\
$40 \mathrm{~mL}$ chromic acid solution & $100 \mathrm{~mL} \mathrm{H}_{2} \mathrm{O}$ \\
$25 \mathrm{~mL} \mathrm{HNO}_{3}$ & (6V applied to solution) \\
\hline Exposure Time: 10 sec. & Exposure Time: $60 \mathrm{sec}$. \\
\hline
\end{tabular}

12 parts $\mathrm{HCl}, 6$ parts $\mathrm{HNO}_{3}, 1$ part $\mathrm{HF}, 1$ part $\mathrm{H}_{2} \mathrm{O}$

23 g chromic acid per $10 \mathrm{~mL} \mathrm{H}_{2} \mathrm{O}$

Electrochemical corrosion tests were performed to evaluate the corrosion process at the weld interface as a function of water chemistry. The galvanic interactions between $\mathrm{Al}$ and SS were suspect. The corrosion tests included potential and galvanic current 
monitoring and potentiodynamic polarization. Samples for electrochemical testing were obtained from the same as-received inertia welded slugs that were used for the irradiated sections. Additional test samples included the Al parent metal, the SS parent metal, and the Heat Affected Zone (HAZ) of the Al. The samples were prepared as metallographic mounts with electrical connections for the electrochemical tests.

The water chemistries were simulated conditions for X02 water, dirty APT water and APT water. For the simulated APT water, laboratory distilled water was used since the impurity levels were low and similar to that anticipated for the APT. The dirty APT water contained $2 \mathrm{ppm} \mathrm{Cl}^{-}$and $7 \mathrm{ppm} \mathrm{SO}_{4}^{-}$. The $\mathrm{XO} 2$ water was a derivative of the dirty APT water with added copper, either $1.0 \mathrm{ppm} \mathrm{Cu}(\mathrm{XO} 2 \mathrm{~b})$ or $0.1 \mathrm{ppm} \mathrm{Cu}(\mathrm{XO} 2 \mathrm{a})$. All the waters were adjusted to a $\mathrm{pH} 5$ with nitric acid and had hydrogen peroxide levels of 0.001 M.

Testing was conducted in a blackened glass cell equipped with gas spargers. When deaerating, nitrogen gas was used. $\mathrm{A} \mathrm{Ag} / \mathrm{AgCl}$ electrode was used as the potential reference and graphite rods were the counter electrodes. A temperature regulated stir/hot plate was used for agitation and heating. All tests were conducted at $30^{\circ} \mathrm{C}$.

\section{Experimental Results and Discussion}

\section{Corrosion}

Over the course of the irradiation, some leaks developed, from other components in Area A, which produced a spray of the cooling water to the exterior of the target/blanket assemblies. Radiolysis of this water in the air environment created a nitric acid spray on the components. Corrosion on the outside of the assemblies was clearly evident following irradiation and has been attributed, primarily, to the presence of the nitric acid, Figure 5.

Visual examination of the sectioned inertia welded transition joints showed the presence of corrosion on not only the exterior of the cooling water tubing but also on the interior of the tubing. The corrosion was evident both on the aluminum section of the cooling water tubing and at the inertia welded interface, Figures 6-7. The stainless steel was relatively unaffected. Differences in the appearance of the corrosion on the aluminum metal and at the inertia welded interface was clearly evident between the different samples. Understanding these results required further characterization through electrochemical testing.

\section{Metallographic Examination}


Samples from each assembly (Mark I, Mark II, and High Flux Assemblies) were sectioned, prepared metallographically, and examined in CMR hot cells. Because $\mathrm{Al}$ and SS are dissimilar metals, the inertia welded interfaces were susceptible to galvanic corrosion. Metallographic examination of the irradiated inertia welds indicated that some of the samples did exhibit degradation at the interface, which is characteristic of galvanic corrosion, Figure 8. However, general corrosion along the length of the aluminum piping
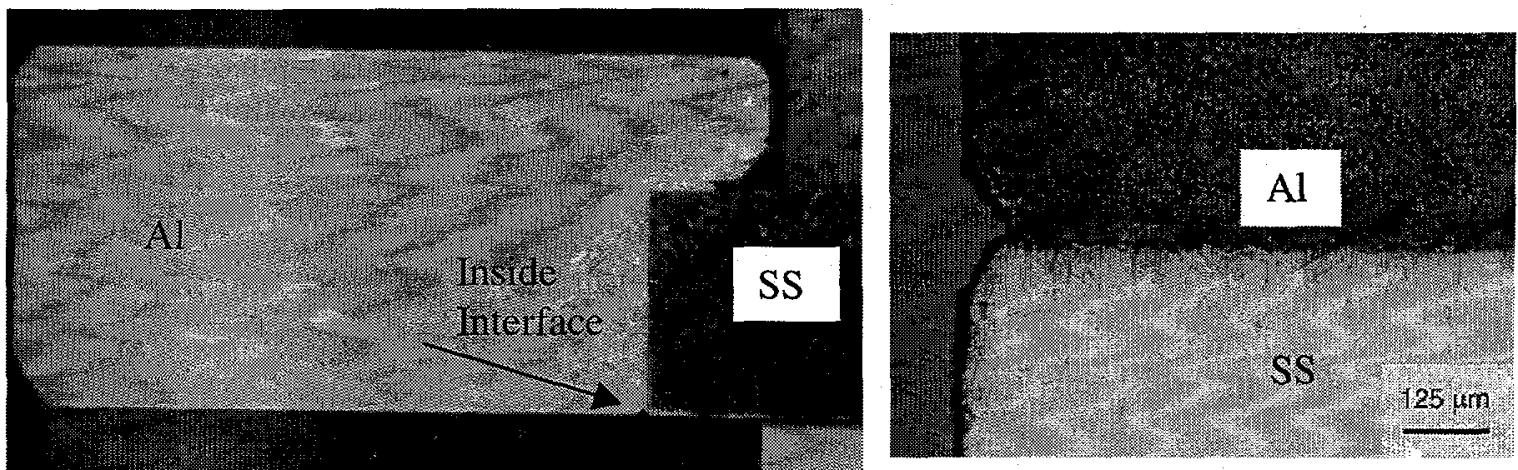

Figure 8. Slight degradation at inertia welded interface on the cooling water side of the High Flux inlet piece (a) macrograph and (b) higher magnification of inside at interface.

and pitting corrosion were more prevalent, Figure 9. The pitting corrosion appeared to present the most severe effects of corrosion. This pitting corrosion, which was located along the piping away from the interface, indicated that the effects of the cooling water chemistry, flow rate, and irradiation on corrosion needed a closer analysis than the effect of the galvanic couple at the SS/Al inertia weld interface. 


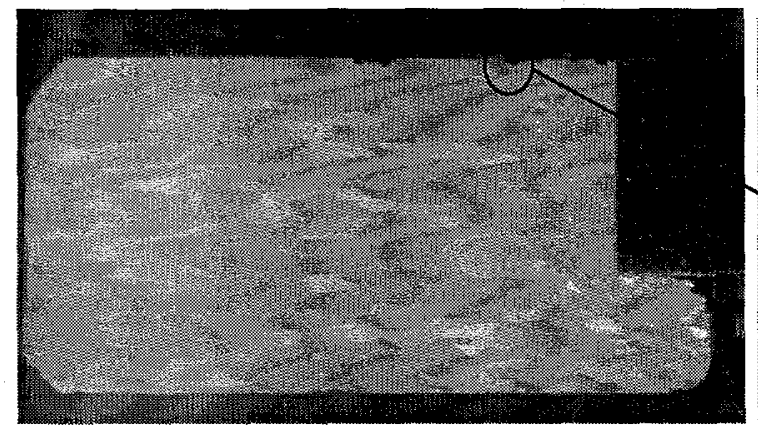

Figure 9. Pitting corrosion along the length of the aluminum on the cooling water side of the Mark I outlet piece (a) macrograph and (b) higher magnification of inside aluminum wall showing representative pitting.

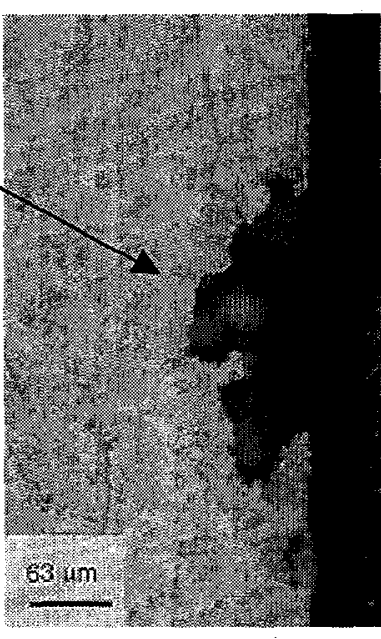

The cooling water used for the Mark I, Mark II and high flux assemblies was provided from the $\mathrm{XO} 2$ system. This $\mathrm{XO} 2$ system contains more impurities than are expected in the APT facility where the water chemistry will be more stringently controlled. Flow of the XO2 cooling water through the $9 \mathrm{~A}$ and $9 \mathrm{C}$ inserts (Mark II and Mark I) was 7.5 and $7.0 \mathrm{gpm}$, respectively, while the flow through the 18B insert (high flux assemblies) was $25.86 \mathrm{gpm}$. As a result of these different cooling water flow rates, oxide thickness on the inside wall of the cooling water piping from the $9 \mathrm{~A}$ and $9 \mathrm{C}$ inserts was approximately 50 $\mu \mathrm{m}$, while the oxide layer on the cooling water piping from the $18 \mathrm{~B}$ insert was

approximately 15 $\mu \mathrm{m}$, Figure 10. The predominant oxide layer was Bayerite, $\left(\beta-\mathrm{Al}_{2} \mathrm{O}_{3} * 3 \mathrm{H}_{2} \mathrm{O}\right)$ because the temperature of the cooling water was maintained at approximately $30^{\circ} \mathrm{C}$. Initially, Gibbsite $(\alpha-$ $\left.\mathrm{Al}_{2} \mathrm{O}_{3} * 3 \mathrm{H}_{2} \mathrm{O}\right)$ is formed before a phase change to
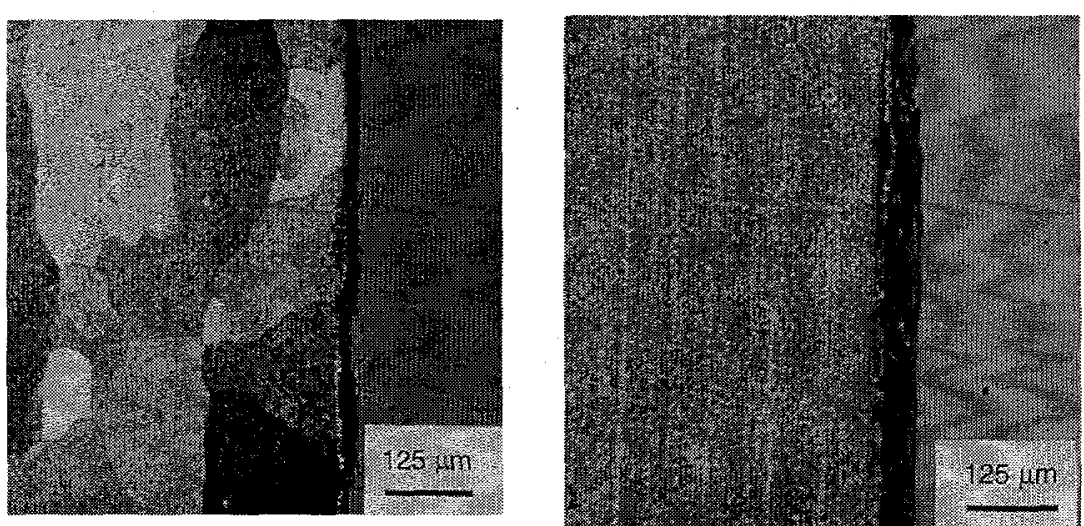

Figure 10. Oxide buildup on inside wall of aluminum cooling water piping near the inertia weld (a) high flux section (25.86 gpm) (b) Mark I section (7.0gpm).

Bayerite [5]. Fifty

microns was the maximum oxide thickness expected for the Area-A test conditions [6].

Another observation made during the metallographic examination was the effect of the recrystallization of the HAZ in the aluminum at the inertia welded interface and grain growth in the aluminum parent material. In each of the unirradiated inertia welded samples prepared for the baseline study, as well as the control sample that was prepared in the CMR hot cells, the HAZ did not show the presence of individual grains in the structure, Figure 11. In addition, the grain structure in the Al parent material of the unirradiated samples shows small equiaxed grains along the outside of the samples with an elongated grain structure near the inside of the samples, Figure 12. However, all of 
the irradiated inertia welded samples showed grain definition in the HAZ of the aluminum, indicating. recrystallization, and grain growth in the $\mathrm{Al}$ parent material (Figure 9(a), 10(a) and 13). The grain growth in the parent material resulted in a fairly consistent grain size throughout the microstructure.

The recrystallization and grain growth is best explained by heating during

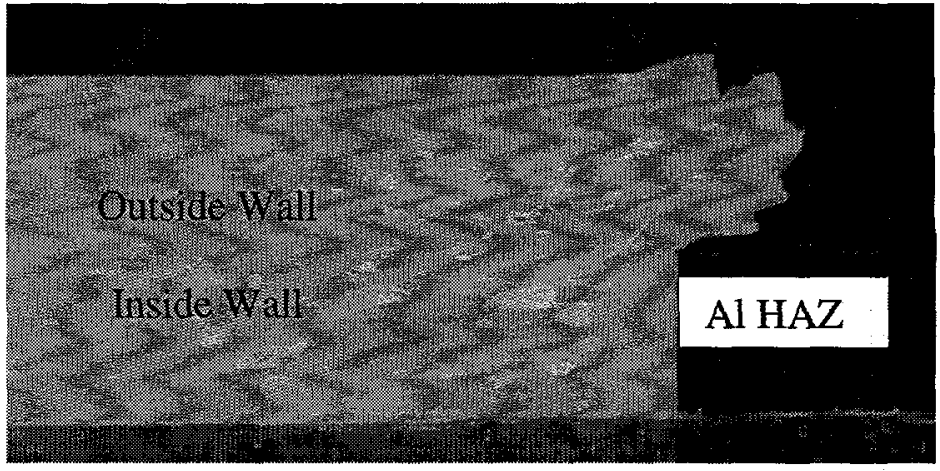

Figure 11. Control sample metallographically prepared in CMR hot cells. Solid inertia welded piece machined to simulate irradiated sections.

welding prior to irradiation especially since these samples received a low dose and the temperatures measured during irradiation, were approximately $30^{\circ} \mathrm{C}$.

Hardness measurements were performed on the non-irradiated as well as the irradiated inertia welded samples to evaluate differences as a result of the recrystallization and grain growth. Hardness values in the non-irradiated samples were higher than the hardness values in the irradiated samples, as shown in Figure 14. These hardness results indicated an aged structure in the irradiated samples and, hence, a reduction in strength. This reduction in strength did not present any deleterious effects during the six month irradiation. However, it must be a consideration in the APT design.

Previous studies measuring the effects of radiation on the strengths of inertia welded tensile specimens indicate that irradiation had a minimal effect on the strength or ductility of the joint [7]. These studies showed, however, that yield strengths of the inertia welds were controlled by the behavior of the $6061 \mathrm{Al}$, and do not reflect the strength of the T6 condition. Inertia welding lowered the yield strength from $275 \mathrm{Mpa}$, typical of 6061-T6 $\mathrm{Al}$, to approximately $170 \mathrm{Mpa}$. To prevent additional losses in yield strength during fabrication, proper cooling techniques will be needed when joining the inertia welded 6061-T6 aluminum to the aluminum tubing in the target/blanket region of the APT facility. 
Figure 14. Hardness vs. Position for Stainless Steel/Aluminum Inertia Welds

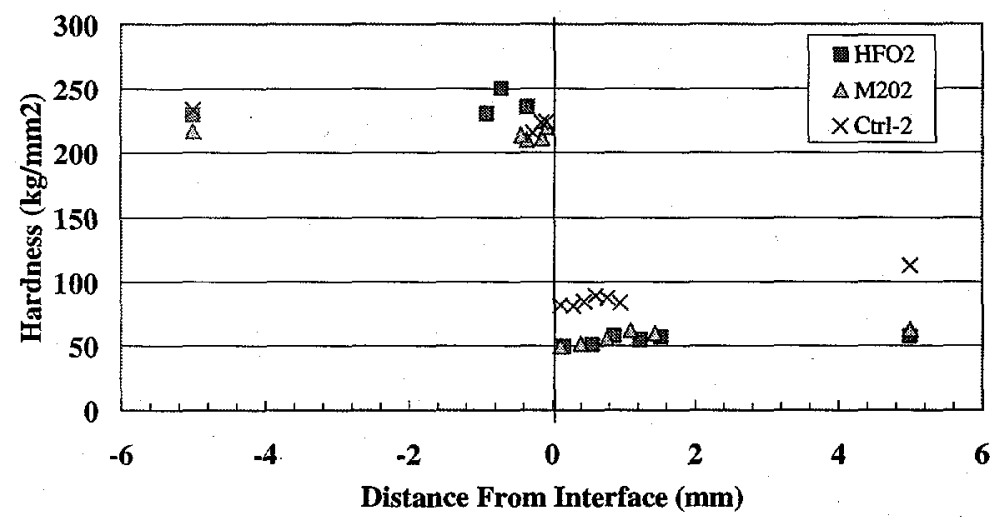

\section{Scanning Electron Microscopy and Energy Dispersive Analysis}

The SEM and EDS study was used to investigate and characterize the inertia welded specimens. The exterior of the piping of the samples generally indicated corrosion product consistent with an aluminum oxide, Figure 15. The interior of the inertia welded specimens showed a high degree of oxidation on the aluminum portion of the specimens, Figure 16, consistent with the previous visual examinations. Several areas observed had portions of the aluminum oxide that had flaked off of the surface, exposing another layer below the outer layer, Figure 16, which again is consistent with earlier findings. The presence of a "mud-flat cracking" appearance was evident on several samples, Figure 17. This flaking of the oxide layer and "mud-flat cracking" is consistent with the presence of Bayerite, which does not adhere well to the surface of the aluminum substrate.

Flow rate of the three assemblies placed in the Area A irradiation were different. Flow of the XO2 cooling water through the 9A and 9C inserts (Mark I and Mark II) was 7.5 and $7.0 \mathrm{gpm}$, respectively, while the flow through the 18B insert (High Flux assemblies) was $25.86 \mathrm{gpm}$. The oxide layer adjacent to the weld interface shown in Figure 16 and 17 (High Flux) has flaked off while 
the oxide layer shown in Figure 18 (Mark II) does not indicate flaking. This observation is consistent with the increased agitation from the flow rate with the High Flux assemblies and the observation made visually and with metallography (Figures 6, 7 and 10).

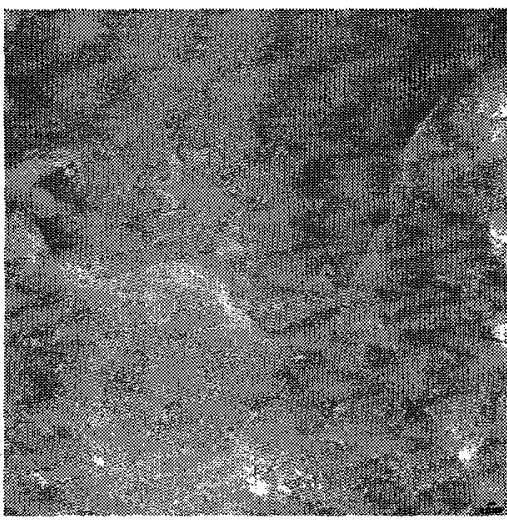

Figure 17. Mudflat cracking of oxide layer in High Flux sample.
Another observation with the SEM was the presence of copper $(\mathrm{Cu})$ rich deposits on the surface of the stainless steel, Figure 19. No evidence of the copper deposits were observed on the aluminum material. However, the $\mathrm{Al}_{2} \mathrm{O}_{3} * 3 \mathrm{H}_{2} \mathrm{O}$ oxide layer was fairly thick and may have masked the presence of the copper deposits. Copper deposits on aluminum are known to cause pitting, which would explain the pitting corrosion observed in the metallographic specimens, Figure 9. The copper deposits were present as a result of the corrosion of the copper beam stop, which was also cooled by the $\mathrm{XO} 2$ cooling water system.

\section{Electrochemical Testing}

Corrosion processes characterized through the electrochemical testing were found to be consistent with those observed on the irradiated inertia welds from the Mark I, Mark II, and high flux assemblies. Galvanic and pitting corrosion were the primary mechanisms, similar

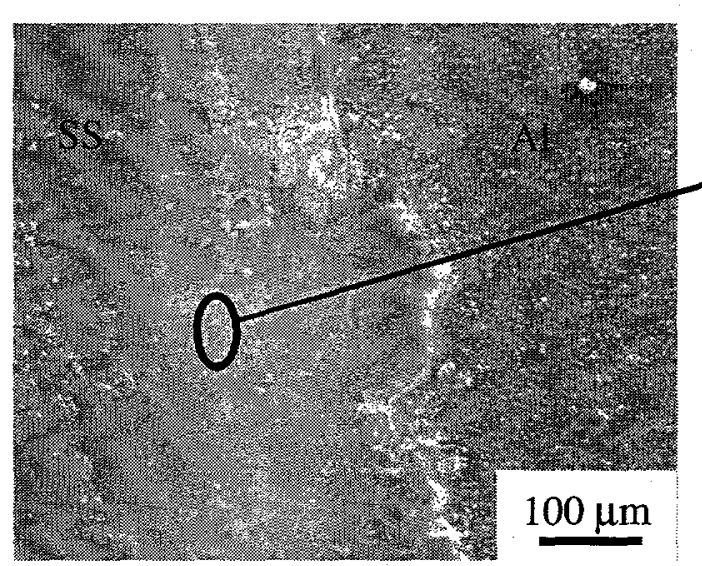

Figure 19. Copper deposits found on stainless steel portion of the inertia weld.

to the irradiated inertia welds. These processes were more aggressive in the water chemistries with higher impurities. XO2 water chemistries produced the most significant pitting and the highest galvanic currents. The test results are summarized in Table 3, which includes the nominal galvanic current 
of the SS/Al couple and open-circuit potentials. The XO2a and XO2b water chemistries contained 0.1 and 1.0 ppm copper ions, respectively.

Open-circuit potential measurements were made on samples of the parent material as well as a section of the weld. As expected, 304L stainless steel was more electropositive than aluminum. The potential of the weld fell between that of the two parent materials. The potential of aluminum was variable for a given water due to the oxide formation dependence on water chemistry. The presence of copper in the XO2 water chemistry caused the potential of both stainless steel and aluminum to shift to more electropositive values. This shift was attributed to the increase in the cathodic reaction due to the reduction of copper.

As the impurity level of the water increased the galvanic current increased. This large galvanic interaction lead to more significant pitting on the aluminum samples. The worst pitting was observed in the XO2 waters. In the XO2 waters, the high degree of pitting was associated with the deposition of copper. The stainless steel sample had the most deposits. Some pitting was also observed on the stainless steel in the XO2b water. These pits were associated with copper deposits on the surface. Few copper deposits were observed on the aluminum sample. The results show that $304 \mathrm{~L}$ stainless steel is the cathode in the couple where the reduction of copper occurs. These results are consistent with those observed on the irradiated inertia welds.

Table 3 - Galvanic Current and Potential Measurements

\begin{tabular}{|l|c|c|c|c|}
\hline $\begin{array}{c}\text { Water Test } \\
\text { Solution }\end{array}$ & $\begin{array}{c}\text { Galvanic } \\
\text { Current }\end{array}$ & $\begin{array}{c}\text { Aluminum } \\
\text { potential }\end{array}$ & $\begin{array}{c}\text { Stainless steel } \\
\text { potential }\end{array}$ & $\begin{array}{c}\text { Weld } \\
\text { potential }\end{array}$ \\
\hline Typical APT & 0.75 & -0.375 & 0.375 & -0.290 \\
\hline Dirty APT & 5.5 & -0.250 & 0.330 & -0.23 \\
\hline XO2a & 7 & -0.225 & 0.400 & ND \\
\hline XO2b & 8.75 & 0.250 & 0.410 & ND \\
\hline
\end{tabular}

\section{Summary}

No leaking at the inertia welded interface was observed following irradiation. The galvanic interaction at the $6061 \mathrm{Al}$ to $304 \mathrm{~L}$ stainless steel inertia welded interface did not present significant degradation as a result of the irradiation or the cooling water chemistry. General corrosion was evident along the entire length of the aluminum piping. Pitting corrosion was present along the aluminum piping and is attributed to conductivity of and copper deposits in the cooling water.

Water chemistry and flow rate are important considerations for the APT design. The reduction or elimination of impurities in the cooling water aids in corrosion control of the aluminum piping and the inertia welded interface. Static or low flow rate of cooling water produced a greater oxide buildup on the aluminum portion of the inertia weld while a higher flow rate induced flaking of the aluminum oxide layer.

Welding of these inertia welded sections to the aluminum cooling water piping caused recrystallization at the aluminum HAZ and grain growth in the parent material. This recrystallization and grain growth in the $\mathrm{Al}$ material resulted in a reduction in 
hardness of the aluminum material. Quality control of the welding procedures for the design and construction of the APT facility will have to be controlled via procedures that outline appropriate cooling mechanisms for the inertia welds.

\section{Acknowledgements}

The authors would like to acknowledge Andy Cheek and Becky Dinkins from WSRC and Toby Romero and Manny Lopez from LANL for their expertise and seemingly endless hours working with the irradiated specimens in the hot cells in the CMR facility at LANL. Also, many thanks to Angela Bowser from WSRC for her excellent laboratory work in support of the electrochemical testing and ?? from LANL for his willingness to spend time on the SEM examining these samples.

\section{References}

[1] Peacock, Jr., H. B., and Leader, D. R., "Design and Fabrication of Prototypical APT Target/Blanket Assemblies and Weld Samples for Area-A Test in the LANSCE Facility at LANL", Internal Report WSRC-TR-96-0180, Westinghouse Savannah River Company, Aiken, SC, April, 1997.

[2] Wadleigh, Al S., "Bi-Metal Welding of Aluminum", Interface Welding, Carson, CA 90746

[3] Dunn, K. A., "Task Technical Plan for Target/Blanket Materials Examination", Internal Report WSRC-RP-98-00038, Westinghouse Savannah River Company, Aiken, SC, May 7, 1998

[4] Dunn, K. A., Tosten, M. H., Louthan, Jr., M. R., Birt, M. L., "Microstructural Characterization of 6061 Aluminum to 304L Stainless Steel Inertia Welds", Conference Proceedings from the $32^{\text {nd }}$ Annual Convention of the International Metallographic Society (Understanding Processing/Structure/Property/Behavior), November, 1999.

[5] Chandler, G. T., Sindelar, R. L., Lam, P. S., "Evaluation of Water Chemistry on the Pitting Susceptibility of Aluminum", Corrosion 97, Paper No. 104, 1997.

[6] Peacock, Jr., H. B., Sindelar, R. L., Lam, P. S., Murphy, T. H., "Evaluation of Corrosion of Aluminum Base Reactor Fuel Cladding Materials During Dry Storage""' Internal Report WSRC-TR-95-0345, Westinghouse Savannah River Company, Aiken, SC, November 1995.

[7] Louthan, M. R., Jr., et al, "Tensile Properties of Welded Alloy 718, 316L and 304L Stainless Steel and 6061 and 5052 Aluminum After Irradiation at the LANSCE Accelerator", Effects of Radiation on Materials, ASTM STP 1405, Proceedings from the $20^{\text {th }}$ Symposium on Effects of Radiation on Materials, June 2000 (To Be Published). 